\title{
Reinvestigation of the Interaction between the RMB Onshore and Offshore Markets: An Empirical Analysis Based on Hourly Data
}

\author{
Zijiao Wang1, Qunyong Wang² \\ ${ }^{1}$ Graduate School of Commerce and Management, Hitotsubashi University, Tokyo, Japan \\ ${ }^{2}$ Economics School, Nankai University, Tianjin, China \\ Email: jojocathy614@gmail.com, QunyongWang@outlook.com
}

How to cite this paper: Wang, Z.J. and Wang, Q.Y. (2017) Reinvestigation of the Interaction between the RMB Onshore and Offshore Markets: An Empirical Analysis Based on Hourly Data. Modern Economy, 8, 1499-1516.

https://doi.org/10.4236/me.2017.812100

Received: November 7, 2017

Accepted: December 9, 2017

Published: December 12, 2017

Copyright $\odot 2017$ by authors and Scientific Research Publishing Inc. This work is licensed under the Creative Commons Attribution International License (CC BY 4.0).

http://creativecommons.org/licenses/by/4.0/

\section{(c) (i) Open Access}

\begin{abstract}
This paper studies the Renminbi (RMB) spot exchange rates against USD to test whether the interaction between the onshore and offshore markets is stable. The Granger Causality test and the BEKK-GARCH model are adopted for five sub-periods, and the results show that the spillover effect in mean and volatility differs in different periods. Our results show that hourly data analysis is a better method detecting the subtle changes of the spot exchange rates between the $\mathrm{CNY}$ and the $\mathrm{CNH}$ markets. There are bidirectional Granger causalities between the $\mathrm{CNY}$ and the $\mathrm{CNH}$ spot exchange rates in both the entire period and the five sub-periods. When the market volatility is high, the impacts become unidirectional by the onshore intervention. The exchange rate of $\mathrm{CNH}$ renders a stronger leading role within the opening year of the offshore market, and then the CNY ones take the guiding role for a long time. The bidirectional interactions between $\mathrm{CNY}$ and $\mathrm{CNH}$ spot exchange rate reveal the information superiority of Chinese government by edging the CNY market over the offshore one, at the same time, readjusting the exchange rate of the CNY based on the $\mathrm{CNH}$ changes in exchange rates in line with market expectations.
\end{abstract}

\section{Keywords}

RMB Onshore and Offshore Markets, Interaction, Hourly Data, Granger Causality, Multivariate GARCH

\section{Introduction}

Since the global financial crisis in 2008, there has been an urgent need for China to have the RMB internationalized for its economic integration into the global 
financial system as well as freedom from USD hegemony ${ }^{1}$. With its rising status in international trade, "China has become the second largest economy after the U.S. and second largest exporter after the euro area... In fact, China has become the most central economy to global trade, supporting demand for the RMB as a currency of settlement for cross-border trade (Maziad, \& Kang, [1])". As long as the USD is the dominant invoicing, investment, and reserve currency in the world, China will always be under risks whenever USD depreciation takes place, for it will cause huge losses to China. As a firm step towards internationalizing its currency, Beijing began to encourage the use of RMB in international trade, swap arrangements between central banks, and bank deposits and bond issuances in Hong Kong (Mallaby \& Wethington, [2]).

The internationalization of the RMB means the use of currency beyond the jurisdiction of China and allows nonresidents to hold the RMB extensively overseas as a currency for routine payments, settlements, investments, and reserves. The RMB internationalization index (RII), compiled by the International Monetary Institute at Renmin University of China (Figure 1), starts from the basic functions of international currencies (measure of value, means of payment, and store of value), and at the same time takes into consideration the functions of international valuation and payment (in trades and finance), and the function of the international reserve. From the time that the pilot scheme of the RMB denominated cross-border trade settlement was announced in 2009, the RMB gradually moved onto the international stage. The RII in the first season of 2010 was 0.02 . The RII has presented a faster growth trend since 2012; when the proportion of the RMB international financial denominated settlement in the world speeded up, the RII presented a faster growth trend. In accordance with the introduction of the RMB cross-border policy, as well as improvement of the RMB offshore and the clearing system, RMB business expanded year-by-year in the international trades, finance and in the foreign exchange reserve. Also, the RII also presented a leap in 2014, reaching a proportion of 2.47. Though the RII fell back somewhat in 2015, because of the domestic downward pressure on the economy, it was still on the rise overall by reaching to 3.60, with an increase of $46 \%$ compared to that in the year before. It is worth mentioning that on November 30, 2015, the IMF's Executive Board decided to include the RMB in the Special Drawing Rights (SDR), which is an important milestone for the RMB on its road to internationalization.

For seven years as a trade settlement currency, the offshore RMB-denominated trade settlement business grew steadily in the international market, the range of holding and using RMB, also expanded, an indication that the Hong Kong offshore market played an important role. As the premier offshore RMB business ${ }^{1}$ As Bowles and Wang [19] noted, "RMB internationalization measures have been introduced as responses to crises-first the Asian financial crisis, then the global financial crisis." Their conclusion is that instead of the "Grand Design" of becoming the world's dominant currency, the internationalization of the RMB has arisen as a policy response to crises, it is only a journey to normalization. 


\section{RII}

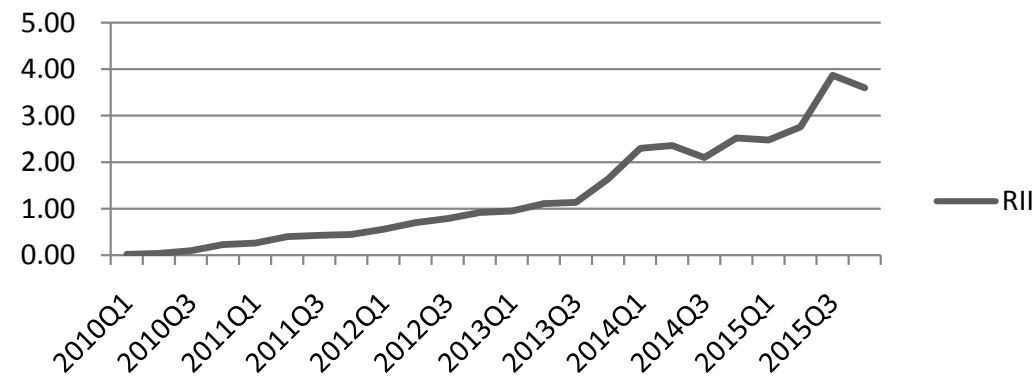

Figure 1. The RMB international index. Source: compiled and made according to the data from the Annual Report on the Internationalization of RMB 2012, 2013, 2014, 2015, 2016 [3], which were compiled by International Monetary Institute at Renmin University. Note: The value range of RII is 0 - 100. The bigger the numerical value is, the higher is the degree of the RMB internationalization.

center, the Hong Kong RMB offshore market ${ }^{2}$ came into being on July 19, 2010, when, the People's Bank of China (PBOC) and the Bank of China (Hong Kong) (BOCHK) signed the amendment of Settlement Agreement on the Clearing of $R M B$ Businesses. Since then, offshore market ${ }^{3}$ have experienced an exponential growth of RMB as a trading currency for cross-border RMB trade settlement. According to the report by BOCHK, the RMB-denominated of trade settlements processed by Hong Kong offshore jumped over 10 times from 369.2 billion yuan in 2010 to 3.841 trillion in 2013. By the end of 2015, the annual value of RMB cross-border trade settlements reached 7.23 trillion yuan ${ }^{4}$, nearly doubled compared with that in 2013. It not only accounts for $29.36 \%$ of China's total foreign exports and imports in 2015, but also increases by $4.6 \%$ from the year before. By then, the $\mathrm{CNH}$ market fully played its role as the important platform to improve the RMB external circulation system in the process of the RMB internationalization. It accounts for $94.5 \%$ of the total annual trade, of which 6.8331 trillion yuan was settled in the Hong Kong offshore market.

According to the Settlement Agreement on the Clearing of RMB Businesses, RMB deposits in Hong Kong can be transferred between banks, and, for enterprises, the upper limits of currency conversion has been removed. Free trade of various financial commodities such as RMB convertibility, RMB deposits, and the issuance of RMB denominated bonds, have become reality. Since then, RMB

${ }^{2}$ In respect of the offshore market, He and McCauley [20] claims, "When non-US residents use the US dollar to settle trade and make investments, they do not transact onshore through banks and in financial markets in the United States. Rather, they concentrate their transactions in international financial centers such as the Eurodollar market in London. In fact, one may argue that, without the offshore markets, the US dollar would not have attained the dominant position in international trade and payments that it occupies today."

${ }^{3}$ In Liu [21]'s view, "Traditional offshore market, such as Eurodollar market, was established mainly to expand business hour and escape regulation, so government wouldn't foster its development. In contrast, $\mathrm{CNH}$ market was officially launched in a high profile manner, and it's regarded as an experiment field for further financial reform in mainland China."

${ }^{4}$ HKMA, 2015. 
foreign exchange markets between Hong Kong banks picked up speed, and continue to enhance the market liquidity, along with an increase of participants based on RMB cross-border trade settlements. In December 2015, the daily trading of RMB and foreign currency on HK offshore market reached 962.7 billion yuan. Meanwhile, the amount of RMB deposits in Hong Kong stood at 851.1 billion yuan ${ }^{5}$.

Unlike the Shanghai CNY market (onshore market) which is regulated by PBOC, RMB-FX (RMB Foreign Exchange) transactions on the offshore market in Hong Kong are wholly determined by market supply and demand, and thus it is called the $\mathrm{CNH}$ market (offshore market). On the one hand, the offshore market fixes its price in accordance with market supply and demand, suitable for transactions between the non-residents in China. So, market participants can buy and sell RMB freely for trading, speculations, investment and so on. On the other hand, the CNY market in Shanghai is subject to the regulation of PBOC, serving all legitimate transactions on mainland China, such as the current account transactions like RMB trade settlements, imports and exports, services, and Foreign Direct Investment (FDI). The onshore and offshore markets also differ in their exchange rate regimes as well as in their market participants and motives (see Table 1). In fact, there has formed a two-tier exchange rate system for the RMB markets, indicating possible interactions between the onshore and the offshore. Since the offshore is free from the PBOC's control, “Unexpected exchange rate fluctuations and exchange rate exposure risks, have been a major source of uncertainty to multinational corporations around the world (Chen, Lee, Lee \& Huang, [4]).” Therefore, it is necessary to reveal these interactions and evidence of spillovers between spot exchange rates on the CNY and CNH markets. The differences between the CNY market and CNH market are exposed in Table 1.

The present research related to interactions between the two markets shows two different perspectives: one view claims a unidirectional correlation from the CNY exchange rate to that of the $\mathrm{CNH}$, i.e. the onshore $\mathrm{RMB}$ spot rate guiding that of the offshore (Xiong, [5]; Maziad, \& Kang, [1]; Zhang, \& Zhong, [6]; Yang, [7]), but not vice versa. The other view is that, being affected by the new exchange rate reform, the relations between the onshore and offshore spot rate is dynamic and time-varying, tending to change from unidirectional correlation to bidirectional interactions, between which the CNY market plays a leading role (Deng, [8]). Most of the research adopted Granger Causality test (Xiong, [5]; Yang, [7]; Owyang, Wong, \& Horowitz, [9], etc.) or GARCH model (Leung, \& Fu, [10]; Maziad, \& Kang, [1], etc.).

The paper makes several contributions. First, the data covers a period of four and a half years from January 3, 2011 to August 10, 2015. Compared with the existing empirical research, this sample presents a more complete view of the changing relation between the two markets. Most sample data in empirical ${ }^{5} \mathrm{HKMA}, 2015$. 
Table 1. Differences between the CNY market and CNH market.

\begin{tabular}{ccc}
\hline Items & CNY markets & CNH markets \\
\hline Financial Products & Spot, Forward, Swap, Options & Spot, Forward, Swap, Options \\
Market Participants & $\begin{array}{c}\text { Residents (onshore bank, financial } \\
\text { company) }\end{array}$ & $\begin{array}{c}\text { Nonresidents (commercial } \\
\text { company, offshore financial } \\
\text { institution, hedge fund) }\end{array}$ \\
Central Bank Intervention & Yes & No \\
Exchange Rate Regime & Managed Floating Exchange Rate & Floating Exchange Rate System \\
Trading Band & System & No \\
Trading Hours & $\pm 2 \%$ & $9: 00-17: 00$ \\
\hline
\end{tabular}

Note: 1) The table is compiled by the writer according to the information dated till August 10, 2015. 2) Until April 15, 2012, the trading band of CNY is $\pm 0.5 \%$, until March 16,2014 , the trading band is $\pm 1 \%$, after then it is $\pm 2 \%$. 3) The trading hour of $\mathrm{CNH}$ exchange is between 9:00 - 17:00 before June 25, 2012, the trading hour is 9:00 - 17:00, then it is 9:00 - 23:00 before October 1, 2014, after then it is 9:00 - 5:00 the next morning.

research is within a two-year period, for example, Xiong [5] covers from August 23, 2010 to June 17, 2011; Maziad and Kang [1] cover from January 3, 2011 to September 16, 2011; only Yang [7] sample data covers more than three years, which is from October 1, 2011 to January 2, 2014. Second, the paper chooses hourly data of RMB transactions to research the exchange rates between CNY and $\mathrm{CNH}$ markets, which can more promptly describe the interactions between the RMB onshore and offshore markets. Most of previous studies employ the closing price as sample data to explore the interactions of spot exchange rates between CNH and CNY. In fact, the CNY market closes earlier than that of $\mathrm{CNH}$ and, as efficient markets respond instantly to new information, this will surely leave space for changes in the latter. Therefore, if the daily closing price is used as the research data, it is hard to detect the prompt changing relationships between the two markets. Thirdly, the whole sample is split into five sub-periods according to external stimulus and policy. The paper analyzes each sub-period to discover whether the relationship between the $\mathrm{CNH}$ and $\mathrm{CNY}$ exchange rates changes or not at different times.

The remaining sections are arranged as follows. The second section introduces our hypothesis about the interaction between the two markets. The third section introduces the data and variables in our analysis, and an econometric analysis is given in Section 4. Section 5 concludes.

\section{Hypothesis}

We focus on interaction of spot exchange rates between the CNY and $\mathrm{CNH}$ markets, excluding the forward exchange rate and NDF (Non-Deliverable Forwards). If we take the forward exchange rate or NDF into consideration on base of spot exchange rate, then we have to consider the changes in interest rates affecting the interaction, which makes the problem more complicated.

As one of the China's national strategies, the establishment and development 
of the RMB offshore are the embodiments of the process to the RMB internationalization. It is different from foreign countries in which the emergence of the offshore markets overseas is spontaneous, e.g. Japan, the United States and the U.K. Direct trading can be done between the onshore and offshore markets with no regulation. Therefore, the exchange rates between the offshore and onshore markets are completely interactive and almost equal. The reasons for the RMB offshore to be different are as follows. First, the offshore market is promoted by China government and not market-oriented. Second, the capital account in China has not achieved free convertibility. Thirdly, the financial management system is still very imperfect. In this way, there are two quite different RMB exchange rate formation mechanisms in the foreign exchange rate markets. The onshore exchange rate formation mechanism is manipulated by the PBOC, and the offshore RMB exchange rate formation mechanism is determined by the market demand and supply. Moreover, the direct trading is forbidden between $\mathrm{CNH}$ and $\mathrm{CNY}$ markets due to the regulation of cross-border capital transactions.

But, restrained by the different exchange rate systems and affected by the participants with different trading motivations, there is a certain price gap between the exchange rates of the two markets, possibility of arbitrage will arise for the store of value, especially when under certain circumstances (cross-border RMB trade settlement), indirect transactions can be made between the two markets, which may also lead to arbitrage. For example, between a parent company in China and its branch company in HK, investors may practice arbitrage transactions by false invoice, though very slim, the offshore takes its shape related to the CNY exchange rate (Sato, [11]). At the same time, the foreign exchange settlement derived from export payment via the commercial or bank agents will also generate revenue from the exchange rate spread. Just as Li [12] points out, "After the promotion of the RMB cross-border trade settlement, the long-expected RMB appreciation overseas causes a higher RMB exchange rate against USD in the offshore market, which will greatly increase the space for enterprises to arbitrage bilaterally." Thus, the existing arbitrage surely causes interactions between $\mathrm{CNH}$ and $\mathrm{CNY}$.

Even though there is no arbitrage, the $\mathrm{CNH}$ and $\mathrm{CNY}$ exchange rates are still mutually interactive, giving rise to bidirectional Granger casualty, as pointed by Murase [13]. Since the CNH exchange rate reflects RMB's market changing trend, the CNY exchange rate may follow that trend, and vice versa. The CNY price mirrors most information about RMB value variations, the price shocks brought by the various information flow will be first reflected in the CNY price, and then transmitted onto the price of $\mathrm{CNH}$ (Wu, [14]).

Thereby, we propose the first hypothesis: there exists Granger Casualty between the $\mathrm{CNH}$ and $\mathrm{CNY}$ exchange rates mutually.

As a managed floating exchange rate system, the RMB exchange rate of the CNY market is only allowed to change within the Trading Band according to the daily reference rate set by the PBOC. In other words, the CNY exchange rate is 
fixed daily by the PBOC, which better reflects the exchange rate policy of the authority, indicating its local advantages compared with the $\mathrm{CNH}$ exchange rate. Therefore, the information is first transmitted from the CNY market to the $\mathrm{CNH}$ market. Despite its rapid development, the offshore market is still smaller than its onshore counterpart, for the transaction volume of the onshore spot market is bigger than that of offshore. Hence, the exchange rate of the CNY market has the initiative to price the RMB, playing a guiding role to the $\mathrm{CNH}$ exchange rate ( $\mathrm{Wu}, \& \mathrm{Pei},[15])$. Leung and $\mathrm{Fu}[10]$ also concluded by their empirical analysis that the CNY exchange rate plays a leading role in the volatility transmission between the two markets because of the recent relaxation of capital control measures and other regulations, which shows the dominant role of the onshore authority in the interactions by monetary policies. Despite the mutual causality between the two markets, the CNY exchange rate plays a leading role.

Thereby hypothesis 2 is proposed: compared with the $\mathrm{CNH}$, the CNY exchange rate is more influential, playing a leading role in the RMB's information transmission.

\section{Data}

Most of the existing relevant studies choose the closing price to study the exchange rate interactions between the onshore and offshore markets. One weakness of daily price is that the onshore market closes earlier than the offshore. At first, there is a 30-minute difference, then, with the $\mathrm{CNH}$ trading hours being extended, the difference expands to 7 hours, and to 12 and a half hours from October 1, 2014 (see Table 1, Note 3). The exchange rate of the offshore market can also be influenced by the closing price of the CNY market. If we analyze using the closing time data, there will be a deviation in the empirical result. Therefore, taking the difference in closing time into account, this paper starts with the hourly data, selecting 7-hour points of CNY and $\mathrm{CNH}$ exchange rates of simultaneous transactions at 10:00, 11:00, 12:00, 13:00, 14:00, 15:00, and 16:00 from January 3, 2011 to August 10, 2015, as well as the closing price for data analysis in comparison. In doing this, it is hoped that we can obtain more sensitive and accurate interconnects between the two markets. The data source is Bloomberg.

This paper splits the whole period into five sub-periods by the influence of external stimulus and policy variation (Figure 2).

Period A: From January 3, 2011 to September 20, 2011. The trading band of the RMB exchange rate against the US Dollar moved $0.5 \%$ below or above the rate set by $\mathrm{PBOC}$ in a single day on average.

Period B: From September 21, 2011 to December 30, 2011. In this period, Italy's sovereign debt rating was downgraded one notch by the American international credit rating agency Standard \& Poor's Corporation. Its negative prospect not only intensified the investors' worries about the European debt crisis, but also stimulated more demands for dollars to hedge risks. Meanwhile the $\mathrm{CNH}$ exchange rate was decreased by a big margin. Besides, in December 2011, some 


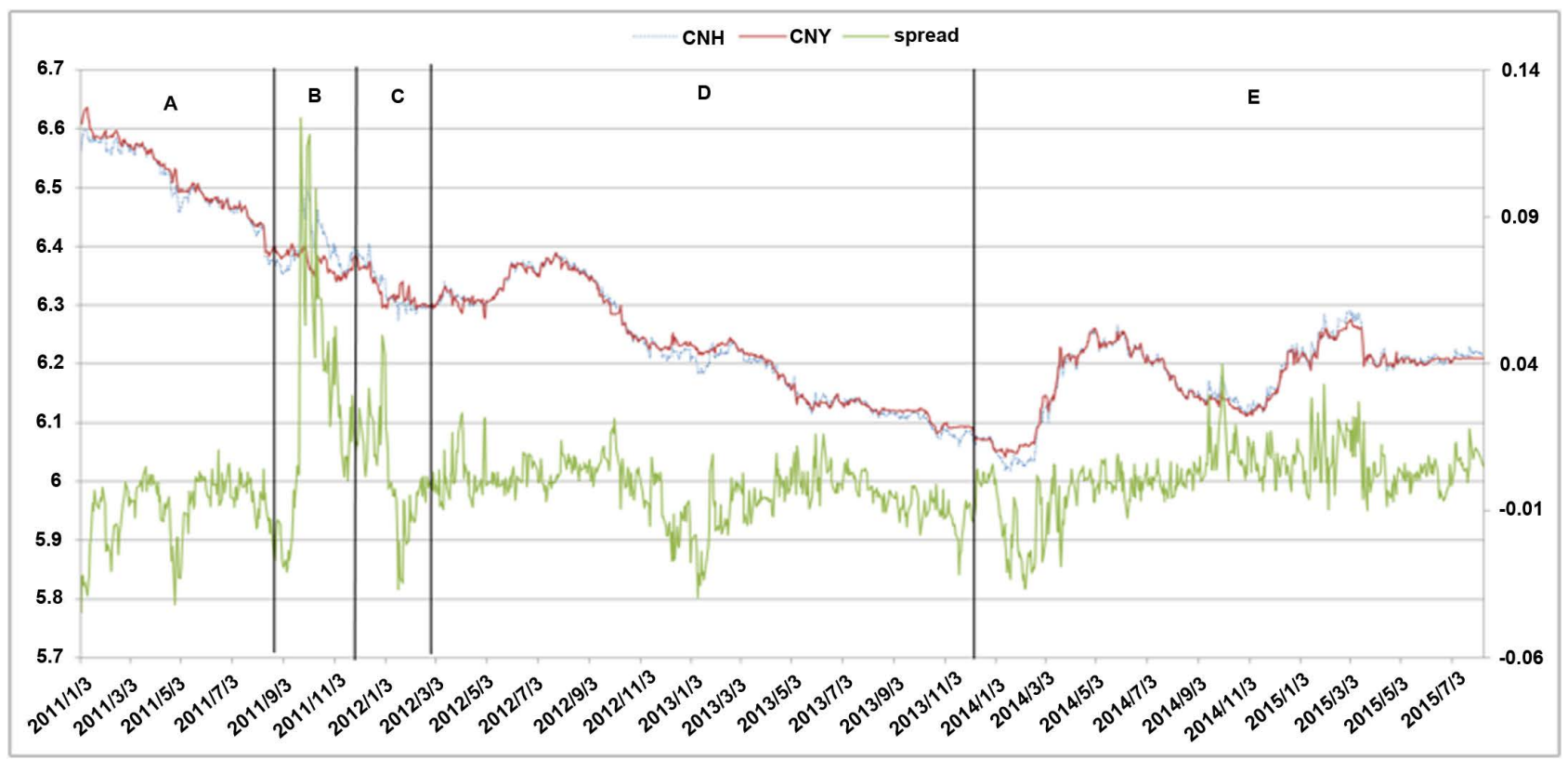

Figure 2. Daily changes of the exchange rates in the CNH and CNY Markets (Yuan/Dollar). Source: Made by the author based on data from Bloomberg. Note: spread $=\mathrm{CNH}-\mathrm{CNY}$.

banks and enterprises in both Europe and America repatriated more capital to their domestic markets to reduce the total indebtedness and improve their balance sheets. Therefore, the RMB weakened against the US dollar, a proof of the RMB's reversal on the Hong Kong offshore market. But the daily trading band of the currency against the US dollars was still $0.5 \%$.

Period C: From January 2, 2012 to April 13, 2012. The daily band of the RMB exchange rate against the U.S. dollar moved on average, above or below $0.5 \%$.

Period D: From April 16, 2012 to March 16, 2014. The PBOC announced that the daily trading band of the RMB exchange rate against the US dollar widened to an average of $1 \%$ above or below the rate set by the $\mathrm{PBOC}$ on any given day since April 16, 2012.

Period E: From March 17, 2014 to August 10, 2015. The PBOC announced that the daily trading band of the RMB exchange rate against the U.S. dollar was widened by $2 \%$ on average for each single day since March 17, 2014.

The CNY is managed floating exchange rate system, restricted by the trading band. The benchmark of the trading band is called "central parity rate" which is announced at 9:15 each day by the China Foreign Exchange Trading Center. The CNY fluctuates within the upper and lower limits of the specified floating range. The central parity rate of Renminbi is calculated by eliminating the highest and lowest quotations which are requested from the market maker in the interbank system everyday, to a weighted average figured out by the China Foreign Exchange Trading Center. It is clearly seen from Figure 3 that the CNY volatility range against the central parity rate maintained within $0.5 \%$ before the exchange rate reform on April $16^{\text {th }}, 2012$, and then the volatility rose to $1 \%$ after the reform. Again, after the exchange rate on March 17, 2014, the volatility range of 


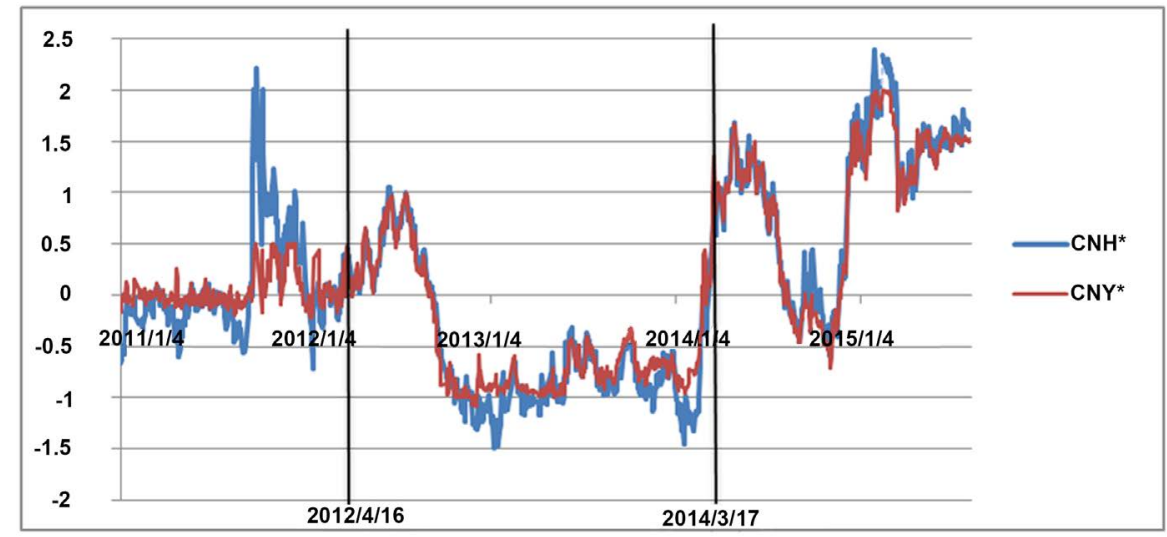

Figure 3. The volatility range between $\mathrm{CNH}$ and CNY (Yuan/Dollar, Closing) against the central parity rate. Source: Made by the author based on data from Bloomberg and SAFE State Administration of Foreign Exchange). Note: $\mathrm{CNH}^{\star}=(\mathrm{CNH}-$ Central parity rate $) /$ Central parity rate ${ }^{\star} 100 ; \mathrm{CNY}^{\star}=(\mathrm{CNY}$-Central parity rate $) /$ Central parity rate ${ }^{\star} 100$.

the CNY rapidly exceeded $1 \%$, and then remained above $1 \%$ after December 2014. Meanwhile, the expansion of the volatility is bound to affect the correlation between the two markets. We can see from Figure 2 and Figure 3, in period $\mathrm{B}$, there is a sharp wave on the $\mathrm{CNH}$ market, the maximum of spread between $\mathrm{CNH}$ and $\mathrm{CNY}$ exceeded 0.12 . Therefore, this paper takes the first step to do the period partition according to the CNY trading band limitation, and then takes out the period affected by the Italy's sovereign debt rating downgraded as a separate period, in which there is greater change for the $\mathrm{CNH}$ exchange rate (Figure 2). Table 2 lists the descriptive statistics of the $\mathrm{CNH}$ and $\mathrm{CNY}$ hourly data.

\section{Empirical Analysis}

To test the stationary time series used in the analysis, the paper employs the Augmented Dicky-Fuller (ADF) unit root test to analyze the stability of the exchange rate of the $\mathrm{CNH}$ and CNY markets. The optimal lag is selected by the AIC. Table 3 lists the results of the unit root test. All the results of the unit root test for the whole period and each sub-period show that, the test for all the level variables accepts the hypothesis and the first differenced variables accept the hypothesis. So, both the $\mathrm{CNH}$ and $\mathrm{CNY}$ exchange rates have one unit root. This paper adopts change rate (the differenced series of the logarithm) for the following econometric models.

By means of the two methods, we can analyze whether the two markets are interactive, as well as the directions and dimensions of the information transmission between them. In this way, we hope to get a better whole view about the interactions between the spot exchange rates of the $\mathrm{CNH}$ and $\mathrm{CNY}$ markets.

\subsection{Spillover in Returns}

The spillover effect is studied in both the return (or mean equation) and volatility (or variance equation) respects. We first employ the Granger causality test to 
Table 2. Descriptive statistics.

\begin{tabular}{cccccccc}
\hline Period & Statistics & Full & A & B & C & D & E \\
\hline CNY & Mean & 6.2644 & 6.5036 & 6.3679 & 6.3230 & 6.2010 & 6.1974 \\
& Max & 6.6346 & 6.6346 & 6.4006 & 6.3847 & 6.3954 & 6.2754 \\
& Min & 6.0410 & 6.3777 & 6.3365 & 6.2865 & 6.0410 & 6.1091 \\
& Sd & 0.1350 & 0.0704 & 0.0164 & 0.0248 & 0.0980 & 0.0413 \\
& Skewness & 0.7316 & -0.1803 & 0.1398 & 0.7282 & 0.3051 & -0.4799 \\
& Kurtosis & 2.9095 & 1.9220 & 1.8495 & 2.2400 & 1.9412 & 2.3555 \\
& Mean & 6.2640 & 6.4938 & 6.4265 & 6.3269 & 6.1963 & 6.2014 \\
& Sd & 6.6015 & 6.6015 & 6.5475 & 6.4170 & 6.3935 & 6.2898 \\
& Min & 6.0192 & 6.3513 & 6.3525 & 6.2868 & 6.0192 & 6.1118 \\
& Max & 0.1365 & 0.0704 & 0.0402 & 0.0319 & 0.1024 & 0.0412 \\
& Skewness & 0.6056 & -0.3854 & 0.5990 & 0.8515 & 0.2975 & -0.3323 \\
& Kurtosis & 2.6679 & 2.0787 & 2.7468 & 2.4401 & 2.0123 & 2.4335 \\
& Obs & 8295 & 1310 & 252 & 784 & 3647 & 2302 \\
\hline
\end{tabular}

Table 3. Result of ADF unit root test.

\begin{tabular}{cccc}
\hline Period & Variable & $y_{t}$ & $\Delta y_{t}$ \\
\hline A & CNH & 0.9333 & $0.0000^{* * *}$ \\
& CNY & 0.9366 & $0.0000^{* *}$ \\
B & CNH & 0.3931 & $0.0000^{* * *}$ \\
& $\mathrm{CNY}$ & 0.1889 & $0.0000^{* * *}$ \\
$\mathrm{C}$ & $\mathrm{CNH}$ & 0.4916 & $0.0000^{* * *}$ \\
& $\mathrm{CNY}$ & 0.3987 & $0.0000^{* * *}$ \\
$\mathrm{D}$ & $\mathrm{CNH}$ & 0.7030 & $0.0001^{* * *}$ \\
& $\mathrm{CNY}$ & 0.6888 & $0.0001^{* * *}$ \\
$\mathrm{CNH}$ & $\mathrm{CNY}$ & 0.6285 & $0.0000^{* * *}$ \\
& $\mathrm{CNH}$ & 0.6803 & $0.0000^{* * *}$ \\
Full sample & $\mathrm{CNY}$ & $0.0843^{*}$ & $0.0000^{* * *}$ \\
& & $0.0705^{*}$ & $0.0001^{* * *}$ \\
\hline
\end{tabular}

Note: ${ }^{* * *}$ denotes the significance at the level of $1 \%$.

verify the causalities of both the entire period and the sub-periods between the $\mathrm{CNH}$ and $\mathrm{CNY}$ exchange rates. The results are manifested in Table 4 via the Granger casualty test:

Over the entire period, there exists bidirectional causality between the two markets and, it is also evident in the sub-periods A, D, and E. Thus, hypothesis 1 is tenable, meaning the two markets are interactive.

The fundamental reason for the result is that the exchange rate of the $\mathrm{CNH}$ reflects not only the changing trend of the RMB, but also the local superiority of 
Table 4. Granger causality test between CNY and CNH.

\begin{tabular}{cccc}
\hline Period & Lag & $\mathrm{CNH} \Rightarrow \mathrm{CNY}$ & $\mathrm{CNY} \Rightarrow \mathrm{CNH}$ \\
\hline Whole & 8 & $0.0000^{* * *}$ & $0.0000^{* * *}$ \\
A & 7 & $0.0248^{* *}$ & $0.0030^{* * *}$ \\
B & 2 & $0.0253^{* *}$ & 0.4557 \\
C & 1 & $0.0408^{* *}$ & 0.8109 \\
D & 8 & $0.0000^{* * *}$ & $0.0084^{* * *}$ \\
E & 3 & $0.0005^{* * *}$ & $0.0004^{* * *}$ \\
\hline
\end{tabular}

Note: ${ }^{* *}{ }^{* * *}$ means the significance at the level of $5 \%$ and $1 \%$ respectively.

the CNY market in information transmission, indicating the interactions between the two markets. The fact that the currency is unified determines the unification and interactions between the $\mathrm{CNH}$ and $\mathrm{CNY}$ from within, despite the different exchange rate systems. The influence of arbitrage cannot be neglected, though in the case of no-arbitrage, the two markets interact with each other. Price difference between the $\mathrm{CNH}$ and $\mathrm{CNY}$ caused by the existence of cross-border capital controls becomes the very reason for the speculation opportunity. Market speculators speculate by taking advantage of the loophole of cross-border RMB trade settlement, giving rise to certain interactions in the exchange rates between the $\mathrm{CNH}$ and $\mathrm{CNY}$ markets. This is essentially an arbitrage of the rate disparity between a restricted China and the free market. If free arbitrage is allowed between the two markets, then the gap should disappear, or near zero. When there is always a spread between the $\mathrm{CNY}$ and $\mathrm{CNH}$ exchange rates, there is little speculation, a proof that the RMB capital regulation is still effective (Figure 2).

But there exists unidirectional causality in the B and C sub-periods from the $\mathrm{CNH}$ to the $\mathrm{CNY}$ exchange rate, with no converse causality. This means that Hypothesis 1 is untenable in these two sub-periods. In order to find out reasons for the unidirectional causality during the $\mathrm{B}$ and $\mathrm{C}$ sub-periods, the average volatility has been calculated between the $\mathrm{CNH}$ and $\mathrm{CNY}$ change rate during each sub-period. We can see that the average volatility of the exchange rate concerning rate of change during the $\mathrm{A}, \mathrm{D}, \mathrm{E}$ sub-periods is about 0.0004 , while the average spillover during the $\mathrm{B}$ and $\mathrm{C}$ sub-periods is relatively larger, at an exchange rate of 0.00202 and 0.0006 on the $\mathrm{CNH}$ market, while that on the CNY is 0.0008 and 0.0006 . The volatility of the two markets is relatively greater during the sub-periods B and C. By the results of the Granger causality test, we can see that, when there is greater volatility on the markets, there is only unidirectional Granger causality from $\mathrm{CNH}$ to $\mathrm{CNY}$.

The reason is that the CNY market has a closed nature with a managed floating exchange rate system, which limits the trading band, and implies the PBOC will intervene in the onshore market according to the market situation. Therefore, the $\mathrm{CNH}$ exchange rate may suggest higher volatility than that of the CNY, 
which is shown more obviously when there is greater market fluctuation. Due to the intervention of the People's Bank of China, the changes of the CNY exchange rate are suppressed when necessary. With the anticipation of the whole trend of the RMB exchange rate, the offshore participants' demand for selling $\mathrm{RMB}$ is still great, therefore investors in the offshore market will ignore the intervened changes of the CNY exchange rate, CNY's influence over $\mathrm{CNH}$ in this case seems to disappear. On the other hand, the offshore market more closely reflects the RMB future trend, even if the CNY exchange rate is intervened upon, the exchange rate of the $\mathrm{CNH}$ will still exert influence over that of the $\mathrm{CNH}$.

\subsection{Volatility Spillover Effect}

In order to investigate the information transmission direction between the two markets, we adopt the multiple GARCH model (BEKK-GARCH model) proposed by Engle and Kroner [16] to test the volatility spillover effects of the two markets. This method is the same as that of Maziad and Kang [1]. The BEKK-GARCH model consists of the mean equation and variance equation. The mean equation is specified as

$$
\left(\begin{array}{l}
y_{1, t} \\
y_{2, t}
\end{array}\right)=\left(\begin{array}{l}
\mu_{1} \\
\mu_{2}
\end{array}\right)+\left(\begin{array}{ll}
\theta_{11} & \theta_{12} \\
\theta_{21} & \theta_{22}
\end{array}\right)\left(\begin{array}{l}
y_{1, t-1} \\
y_{2, t-1}
\end{array}\right)+\left(\begin{array}{c}
\varepsilon_{1, t} \\
\varepsilon_{2, t}
\end{array}\right), \varepsilon_{t} \sim \operatorname{Normal}\left(0, H_{t}\right) .
$$

where $y_{t}$ refers to the return rate of exchange rates in the onshore and offshore markets. The subscript 1 is the $\mathrm{CNH}$ exchange rate, and the subscript 2 is the $\mathrm{CNY}$ exchange rate. $\theta$ refers to the influence the $\mathrm{CNH}$ exchange rate $(\mathrm{CNY}$ exchange rate) volatility in $t-1$ phase has on the volatility of the CNY exchange ( $\mathrm{CNH}$ exchange rate) rate in the phase of t. $\varepsilon_{t}$ is the residual term of the mean equation, under the information set before 1 phase, obeying the mean value of 0 variance which is the normal distribution of $H_{t}$.

The variance equation is specified as

$$
H_{t}=C^{\prime} C+A^{\prime} \varepsilon_{t-1} \varepsilon_{t-1} A^{\prime}+B^{\prime} H_{t-1} B
$$

where

$$
H_{t}=\left(\begin{array}{cc}
\sigma_{1, t}^{2} & \sigma_{12, t} \\
\sigma_{12, t} & \sigma_{2, t}^{2}
\end{array}\right), C=\left(\begin{array}{cc}
c_{11} & 0 \\
c_{21} & c_{22}
\end{array}\right), A=\left(\begin{array}{ll}
a_{11} & a_{12} \\
a_{21} & a_{22}
\end{array}\right), B=\left(\begin{array}{ll}
b_{11} & b_{12} \\
b_{21} & b_{22}
\end{array}\right)
$$

$C$ is a lower triangular matrix. $A$ is a $2 \times 2$ matrix, referring to the coefficient of $\mathrm{ARCH}$ term which represents the degree of influence from the random disturbances with past value of the return rate series over the current conditional variance. While the diagonal parameter is used to measure the early impact of the single market on the current volatility, the non-diagonal parameter is used to evaluate the shock spillover effect between the two markets. $B$ is a $2 \times 2$ matrix, referring to GARCH term coefficient which represents the degree of influence from the predictive conditional variance with past value of the return rate series over the current conditional variance. The diagonal parameter is used to evaluate the continuity of volatility persistence of the single market; while the 
non-diagonal parameter is used to designate the volatility spillover between the two markets.

The non-diagonal parameter is employed to verify the spillover between the two markets, and the four variables are drawn as follows. $a_{12}$ is the shock spillover effect from the $\mathrm{CNH}$ market to the $\mathrm{CNY}$ market. $a_{21}$ is the shock spillover effect from the CNY market to the CHH market. $b_{12}$ is the volatility spillover effect from the $\mathrm{CNH}$ market to the $\mathrm{CNY}$ market. $b_{21}$ is the volatility spillover effect from the CNY market to the $\mathrm{CNH}$ market.

Table 5 shows that in the periods of $\mathrm{C}, \mathrm{D}$ and over the entire period, positive effects of bidirectional shock spillover appear between the exchange rates of the $\mathrm{CNH}$ and $\mathrm{CNY}$. In the periods of $\mathrm{C}$ and $\mathrm{D}$, the shock spillover effects of exchange rate from $\mathrm{CNH}$ to $\mathrm{CNY}$ are higher than that from $\mathrm{CNY}$ to $\mathrm{CNH}$, while, the result of the entire period is just the opposite.

The calculation results of the conditional variance equation show that, in period $\mathrm{A}$, when the exchange rate of CNH's conditional standard deviation increase by $1 \%$, the exchange rate of CNY's conditional standard deviation will increase by $0.3504 \%$ in the next period, which is the maximum value in Table 5 . Thus, there is unidirectional volatility spillover of significant numerical value from the $\mathrm{CNH}$ exchange rate to that of the CNY. Therefore, hypothesis 2 is untenable.

That is because, period A covers from January 3, 2011 to September 20, 2011, within a year after the $\mathrm{CNH}$ was open. Since the exchange rate of the $\mathrm{CNH}$ depends on market demand and supply, it plays a stronger leading role in information transmission in that year. As we know, RMB cannot be traded freely on the onshore market, so the appearance of a free trading offshore RMB market not only meets the needs of foreign investors in $\mathrm{RMB}$, but also convinces the market participants of the Chinese Government's determination on RMB internationalization. The changes of the offshore market's spot exchange rates fully express the international expectations of the RMB's future trend, which is the reason why its stronger volatility spillover directs that of the CHY in the first year after its opening and pushes for the currency's appreciation.

Meanwhile, the exchange rates of the CNY in periods C, D and during the whole period show unidirectional volatility spillover effects to that of the $\mathrm{CNH}$ of $0.0074,0.0247$, and 0.0769 respectively. Compared with period A, the volatility spillover effects are relatively smaller, but with longer duration. Results show,

Table 5. Results of BEKK-GARCH.

\begin{tabular}{cccccccc}
\hline Spillover & Direction & Whole & $\mathrm{A}$ & $\mathrm{B}$ & $\mathrm{C}$ & $\mathrm{D}$ & $\mathrm{E}$ \\
\hline \multirow{2}{*}{ Mean } & $\mathrm{CNH} \rightarrow \mathrm{CNY}$ & $0.0027^{* *}$ & -0.2606 & -0.0086 & $0.0761^{\star *}$ & $0.1086^{* * *}$ & 0.0210 \\
& $\mathrm{CNY} \rightarrow \mathrm{CNH}$ & $0.1023^{* *}$ & 0.076 & -0.0012 & $0.0572^{* * *}$ & $0.0361^{* * *}$ & -0.1592 \\
& $\mathrm{CNH} \rightarrow \mathrm{CNY}$ & 0.0005 & $0.3504^{* *}$ & -0.0091 & -0.0105 & -0.0162 & -0.0010 \\
\multirow{2}{*}{ Volatility } & $\mathrm{CNY} \rightarrow \mathrm{CNH}$ & $0.0769^{* * *}$ & -0.0634 & 0.0113 & $0.0074^{* * *}$ & $0.0247^{* * *}$ & 0.0002 \\
\hline
\end{tabular}

Note: ${ }^{* *}{ }^{* * *}$ means the significance at the level of $5 \%$ and $1 \%$ respectively. 
in periods $\mathrm{C}$ and $\mathrm{D}$ and the whole period, the CNY market plays a stronger leading role. Hypothesis 2 is tenable.

The novelty gradually wore off after the opening year and, the offshore market tends to be stable. As a managed floating exchange rate system, the exchange rates of the CNY market change over the upper and lower bands of the daily central parity rate set by the China Foreign Exchange Trading Center at 9:15, whereas publishing the central parity rate is equivalent to RMB pricing set daily by the PBOC, which manipulates price changes of the onshore RMB market. At the same time, the onshore RMB enjoys more local information superiority, which guarantees the onshore market with a transaction volume of 1.5 times as much as that of the offshore market ${ }^{6}$ in spot exchange rates, allowing the CNY exchange rate to play a dominant role in RMB exchange rate marketization over a long period.

\section{Conclusions and Suggestions}

The internationalized RMB has entered major countries worldwide. The Daily Mail reported "China leapfrogs the U.S. to become the world's largest trading nation with $£ 2.45$ trillion in imports and exports" [17]. By the end of 2015, China surpassed America to take the title of the world's biggest goods trading nation, and the RMB has become the fourth largest currency in the world for cross-border payment. The PBOC has set up RMB Clearance Arrangement mechanisms with more than 20 countries, with the RMB business services covering nearly 200 countries and regions. Besides Hong Kong, Singapore and London emerged as two other RMB offshore markets developing a diversified range of $\mathrm{RMB}$ products including deposits, exchange and remittance, investment and $\mathrm{RMB}$ bonds service to meet the demands of the international market.

The changes between the exchange rate of CNY and that of $\mathrm{CNH}$ reflect not only the interactions of the two markets, but also the international financial shock. Since the hourly data analysis can remove the effects caused by the different closing time of the two markets, compared with the previous studies, this paper draws different conclusions as follows:

First, the result shows that there is a bidirectional Granger causality between $\mathrm{CNY}$ exchange rates and the $\mathrm{CNH}$ ones. When the volatility is high, the impacts of the exchange rate from $\mathrm{CNY}$ to that of $\mathrm{CNH}$ disappear with the onshore intervention.

Secondly, there is a bidirectional Granger causality between the exchange rates of the $\mathrm{CNY}$ and $\mathrm{CNH}$ markets that is not detected by closing time analysis. Looking at the volatility result, within the opening year of the offshore market, we see the exchange rate of the $\mathrm{CNH}$ takes a stronger leading role. After that, the market participants gradually calm down from the fervent demand for $\mathrm{CNH}$ market and return to normal; the CNY exchange rates guide the RMB exchange

${ }^{6}$ Calculated by data from Funke et al. [22]. The time point is Q4, 2013. 
rates for a long time.

Thirdly, based upon the above conclusions, hourly data analysis is a better method for detecting the subtle changes of the spot exchange rates between the onshore and the offshore markets, especially the latter, which signify more implications of the global market information. The fact of the bidirectional interactions between the $\mathrm{CNY}$ and $\mathrm{CNH}$ spot exchange rate gives the Chinese government information superiority ${ }^{7}$ by edging the CNY market over the offshore one, at the same time, readjusting the exchange rate of the CNY based on the changes in exchange rates of the $\mathrm{CNH}$ in line with market expectations.

The RMB internationalization is generally embodied by three aspects: as a global trade settlement currency, as a global investment currency and as a global reserve currency. In terms of China's economic growth rate, the RMB is far from matching these steps. While China has become the globe's second largest economy, the RMB's status only ranks the fourth international currency. Though the RMB-denominated trades grew significantly from $11 \%$ of China's foreign trade in 2012 up to $29.3 \%$ in 2015 , more than $75 \%$ proportion of trade was settled in U.S. dollars. It is clearly why China is determined to internationalize the RMB.

Because of the capital control, China has partially realized RMB internationalization. With less than 1/3 RMB denominated trades and the very limited "dim-sum" bands being issued, RMB as a global reserve currency remains unlikely to be seen. In fact, pushing RMB internationalization is integrated with the development of the offshore markets. The capital control and the financial liberalization go in inverse proportion, the more control, the less liberalization, but, of course with less risks. Conversely, internationalization asks for more relaxation on regulation, more relaxation means, more internationalization, but certainly, with more risks. So, it is said that RMB internationalization is a double-edged sword, just as Huang and Lynch [18] points out: "While internationalization carries long-term benefits such as heightened prestige and influence, greater say in the international system, and improved trade efficiency, there are also increased risks-namely, more volatility, increased exposure to external shocks, and potential loss of control over domestic monetary policy."

Developments in the offshore markets are demonstrations of the RMB's internationalization. Yet, how to promote RMB internationalization on the base of more open offshore markets is subject to reforms in the financial system, fiscal policies and the liberalization of capital accounts. Fundamentally, the RMB internationalization aims at domestic reforms in financial system, which will only be done by sacrificing the internal stability of China's financial markets. Therefore, the liberalization of exchange rate is impossible in the short term, for the guiding role of the offshore exchange rates has revealed risks of international volatility. Consequently, relaxation of the regulation means greater risks, as de${ }^{7}$ As Liu [21] points out, "China's FX market, however, is in an odd position where CNY market has relatively richer liquidity but not enough volatility, whereas $\mathrm{CNH}$ market is dominated by excessive volatility due to the lack of liquidity. The integration of onshore and offshore market remains a long way ahead, even after the eventful year of 2014". 
scribed by the often-cited Triffin dilemma ${ }^{8}$, which China might avoid now by holding reserves in SDRS. With inherent imperfections in the financial systems, China is doomed to carry out relative reforms. Therefore, the author puts out four suggestions:

1) Starting planned and step-by-step deregulation of the exchange rates. Just as we witnessed the RMB trading band went from 0.5\% (before April 2012) up to $2 \%$ (after March 2014) year by year, China should maintain its own pace in relaxing the trading band with more perfect measures of financial regulations. On the one hand, to make it more flexible; on the other hand, to increase more diversified market participants, to both avoid the risks brought by single market preference and keep the market exchange rates relatively stable.

2) Consolidating risk managements in case of bigger exchange rate fluctuation. With more flexible exchange rates, the financial institutions, import and export enterprises are under more exchange rate risks. Therefore, the government and related enterprises have to improve their ability to hedge foreign exchange risk with more efforts put into risk management.

3) Continuously monitoring while relaxing capital controls. When there are external shocks, the RMB offshore exchange rate will inevitably affect the onshore one, and further endanger the security of the domestic financial market. Accordingly, it is strongly suggested that the government should be scrupulous in promoting the consistent monitoring of capital account liberalization, for it may increase risks of RMB outflows. The failure of the Western liberalized financial order is a good lesson.

4) Improving the domestic financial system and promoting financial reform. The realization of floating exchange rate regime is the precondition of the RMB's internationalization, meaning complete capital liberalization. But the prerequisite for all these is the improvement and reform of the domestic financial system, which calls for the liberalization of both exchange rates and capital, and inevitably, opens the system to international shocks.

\section{References}

[1] Maziad, S. and Kang, J.S. (2012) RMB Internationalization: Onshore/Offshore Links. IMF Working Paper, No. 12/133.

[2] Mallaby, S. and Wethington, O. (2012) The Future of the Yuan, China's Struggle to Internationalize Its Currency. Foreign Affairs, 91, 135-146.

${ }^{8}$ The Triffin dilemma or Triffin paradox is the conflict of economic interests that arises between short-term domestic and long-term international objectives for countries whose currencies serve as global reserve currencies. This dilemma was first identified in the 1960 s by Belgian-American economist Robert Triffin, who pointed out that the country whose currency, being the global reserve currency, foreign nations wish to hold, must be willing to supply the world with an extra supply of its currency to fulfill world demand for these foreign exchange reserves, thus leading to a trade deficit.

${ }^{9}$ In Lee [23]'s view, "Despite important progress in financial reform and opening over the past decades, the Chinese financial system is still far from an open, sound and efficient one. It is a critical question whether China can continue to do financial liberalization and opening with adequate pace and sequencing." 
[3] International Monetary Institute (2012-2016) Annual Report on the Internationalization of RMB, 2012-2016. China Renmin University Press, Beijing.

[4] Chen, P.F., Lee, C.C., Lee, C.C. and Huang, J.X. (2016) A Dynamic Analysis of Exchange Rate Exposure: The Impact of China's RMB. The World Economy, 39, 132-157. https://doi.org/10.1111/twec.12365

[5] Xiong, L. (2011) An Empirical Study on the Interactive Relations between the Overseas and Domestic RMB Exchange Rates-Based on Data after the Establishment of the Hong Kong Offshore Market. Finance and Economy, 10, 51-56.

[6] Zhang, H. and Zhong, Z. (2014) An Empirical Study on the Interactions between the RMB Onshore and Hong Kong Offshore Markets. Research of Finance and Education, 4, 8-14.

[7] Yang, C. (2014) A Study on the Interactive Relations between the RMB Offshore and Onshore Markets. China Finance Press, Beijing.

[8] Deng, C. (2016) Study on the Relationship between the Remuneration Spillover and Volatility Spillover of the RMB Onshore and Offshore Market. Journal of Translation from Literature of Economics, 1, 38-48.

[9] Owyong, D., Wong, W. and Horowitz, I. (2015) Cointegration and Causality among the Onshore and Offshore Markets for China's Currency. Journal of Asian Economics, 41, 20-38. https://doi.org/10.1016/j.asieco.2015.10.004

[10] Leung, D. and Fu, J. (2014) Interactions between CNY and CNH Money and Forward Exchange Markets. HKIMR Working Paper, No. 13.

[11] Sato, M. (2012) The RMB Offshore Market in Hong Kong-A Report on On-the-Spot Investigation. Newsletter. http: //www.iima.or.jp/Docs/newsletter/2012/NLNo_32_j.pdf

[12] Li, X. (2011) The RMB Internationalization-The Background, History and Problems. Business \& Economic Review, 21, 22-42.

[13] Murase, T. (2013) The Key for the RMB Internationalization Is Capital Liberalization and Financial Reform. International Economic and Financial Review. https: //www.iima.or.jp/Docs/report/2013/no1_2013.pdf

[14] Wu, T. (2015) Analysis on the Interactive Relationships between CNH and CNY, Journal of Anhui Agricultural University (Social Science Edition), 3, 46-49, 92.

[15] Wu, G. and Pei, C. (2012) A Quantitative Study on the Price Relationships between the RMB Overseas and Domestic Exchange Rates. Journal of Financial Research, 9, 62-73.

[16] Engle, R.F. and Kroner, K.F. (1995) Multivariate Simultaneous Generalized ARCH. Econometric Theory, 11, 122-150. https://doi.org/10.1017/S0266466600009063

[17] Duncan, H. (2013) China Leapfrogs the U.S. to Become the World's Largest Trading Nation with $£ 2.45$ Trillion in Imports and Exports. The Daily Mail. http://www.dailymail.co.uk/news/article-2277254/China-Becomes-worlds-largest-tr ading-nation-ahead-America.html

[18] Huang, Y. and Lynch, C. (2013) Does Internationalizing the RMB Make Sense for China? Cato Journal, 33, 571-585.

[19] Bowles, P. and Wang, B. (2013) RMB Internationalization, A Journey to Where? Development \& Change, 44, 1363-1385. https://doi.org/10.1111/dech.12058

[20] He, D. and McCauley, R.N. (2010) Offshore Market for the Domestic Currency: Monetary and Financial Stability Issues. BIS Working Paper, No. 320.

[21] Liu, T. (2015) The Onshore-Offshore Interaction of RMB Market: A High-Frequency Analysis. MPRA Paper, No. 64057. 
[22] Funke, M., Shu, C., Cheng, X. and Eraslan, S. (2015) Assessing the CNH-CNY Pricing Differential: Role of Fundamentals, Contagion and Policy. Journal of International Money and Finance, 59, 245-262.

https://doi.org/10.1016/j.jimonfin.2015.07.008

[23] Lee, J.W. (2014) Will the RMB Emerge as an International Reserve Currency? The World Economy, 37, 42-62. https://doi.org/10.1111/twec.12092 